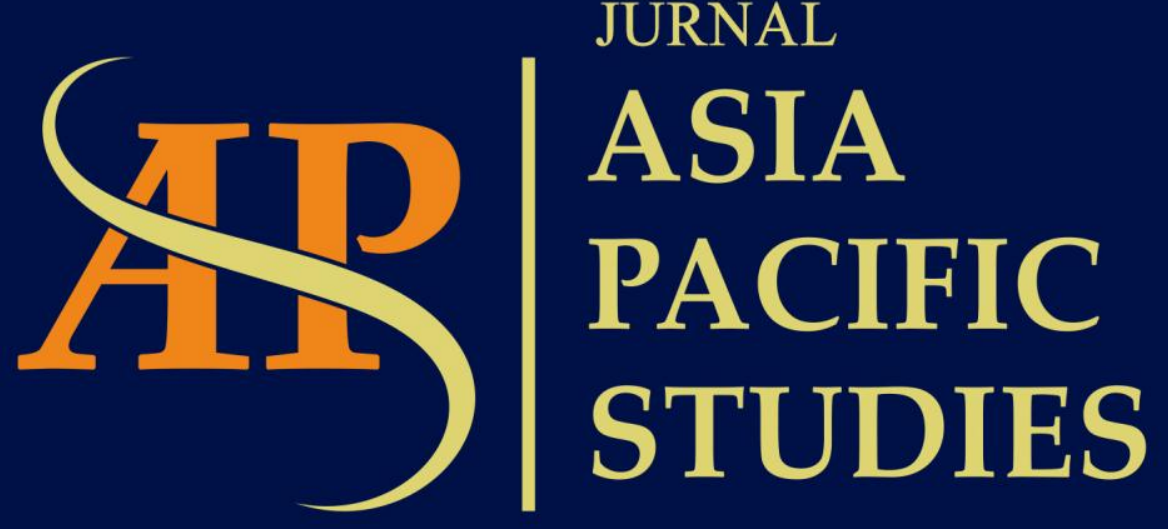

Journal of International Relations Study Program Faculty of Social and Political Sciences

Universitas Kristen Indonesia

Volume 2 | Number 1 | January - June 2018 


\title{
HIGHER EDUCATION WITHIN ASEAN CONNECTIVITY
}

\author{
${ }^{1}$ Yuliana R. Prasetyawati; ${ }^{2}$ Cornelia Alverina \\ ${ }^{1}$ Head of Centre For ASEAN Public Relation Studies, LSPR - Jakarta, \\ Jl. K.H. Mas Mansyur Kav. 35 Sudirman Park, Central Jakarta, 10220, Indonesia \\ ${ }^{2}$ Postgraduate Students, LSPR - Jakarta, \\ Jl. K.H. Mas Mansyur Kav. 35 Sudirman Park, Central Jakarta, 10220, Indonesia \\ 1yuliana.rp@lspr.edu; 22cornelia.a@lspr.edu
}

\begin{abstract}
ASEAN member countries are well aware of the importance of education as one of the decisive factors in developing a high quality of human resources. This is reflected in the inclusion of education in ASEAN socio cultural cooperation dimension. This review will highlight the implementation of higher education in ASEAN connectivity described in five steps. Infrastructure connectivity makes the mobility of young people in ASEAN members become easier in pursuing education across ASEAN region. In addition, the improvement of facilities and infrastructure in educational institutions could support a conducive atmosphere in the teaching and learning process. Institutional connectivity could also develop human resources who are not only knowledgeable but also have compatible skills with industrial needs in ASEAN. In regional level, connectivity through ASEAN University Network will develop quality standards between AUN members which can be used as a benchmark standard of university quality in ASEAN. Young generation connectivity through students' exchange program between many universities in ASEAN are not only for knowledge exchange but also to understand each other's cultural diversity. Connectivity is the success key in building the ASEAN community. Connectivity plays a role in helping to reduce education gaps among ASEAN member countries. Higher education within ASEAN connectivity will strengthen regional cooperation between university institutions and students in ASEAN, also will enhance the internationalization of competitive and high-quality education.
\end{abstract}

Keywords: connectivity, ASEAN, education

\begin{abstract}
Negara-negara anggota ASEAN sangat menyadari pentingnya bidang pendidikan menjadi salah satu faktor penentu membangun sumber daya manusia yang berkualitas. Hal ini tercermin dengan dimasukkannya pendidikan dalam dimensi kerja sama sosial budaya ASEAN. Kajian ini akan menyoroti mengenai implementasi pendidikan dalam konektivitas ASEAN yang diuraikan dalam lima langkah. Konektivitas infrastruktur akan mempermudah mobilitas para generasi muda ASEAN untuk menempuh pendidikan lintas wilayah ASEAN. Selain itu, perbaikan sarana dan prasarana dalam institusi pendidikan akan mendukung suasana yang kondusif dalam proses belajar mengajar. Konektivitas institusional juga akan menghasilkan SDM yang bukan hanya memiliki pengetahuan namun juga memiliki ketrampilan yang sesuai dengan kebutuhan industri di ASEAN. Pada level regional, konektivitas melalui ASEAN University Network akan membangun standar kualitas antar anggota AUN dapat dijadikan sebagai tolak ukur standar kualitas Perguruan Tinggi di ASEAN. Konektivitas generasi muda melalui pertukaran mahasiswa di berbagai universitas di ASEAN bukan hanya berbagi pengetahuan namun juga saling memahami keberagaman budaya. Konektivitas merupakan kunci keberhasilan dalam membangun ASEAN Community. Konektivitas berperan membantu memperkecil kesenjangan pendidikan di negara-negara anggota ASEAN. Pendidikan dalam frame konektivitas ASEAN akan memperkuat kerjasama regional antar-institusi perguruan tinggi dan mahasiswa di ASEAN dan meningkatkan internasionalisasi pendidikan yang berdaya saing dan berkualitas.
\end{abstract}

Kata kunci: konektivitas, ASEAN, pendidikan 


\section{Introduction}

There were lots of achievements in Socio-Cultural Pillars that gave beneficial contributions to its country members in the 50 years of ASEAN presences. One of the most important achievements was when most of Minister of Educations of ASEAN countries collaborated with The Southeast Asian Ministers of Education Organization (SEAMEO) and launch ASEAN Curriculum Sourcebook (ACS) in 2012. ACS is the guide to teach about ASEAN in elementary, junior and senior high school level.

Collaboration in educational sector in ASEAN was marked by the approval in strengthening cooperation declaration through Cha-Am Hua Hin "Declaration on Strengthening Cooperation on Education to Achieve an ASEAN Caring and Sharing Community" in the $15^{\text {th }}$ ASEAN Summit in Hua Hin, Thailand on October 23-25, 2009. The reinforcement in educational cooperation that aims to improve the quality of human resources so that this will lead to competitiveness edge at both regional and global level. It also expressed the hope of ASEAN countries to establish research conventions in education field. In this regard, ASEAN member countries are also required to improve education competency standards and improve professional standards of their teaching staff.

As quoted by Times Higher Education in 2016, it was only the university from Singapore throughout ASEAN, which entered the 200 best universities in the world. This indicated that universities in ASEAN need to improve their quality rapidly in order to develop human resources who can compete regionally and globally.

Besides, another challenge for ASEAN in improving the quality of education is the diversity of education systems in the 10 ASEAN member countries. This was conveyed in the policy dialogue of the European Union Support to Higher Education In The ASEAN Region (SHARE) which discussed the quality assurance of ASEAN higher education system. Nantana Gajaseni, the Executive Director of ASEAN University Network (AUN), stated that those diversities in ASEAN countries' education system is the differentiator for higher education quality improvement between ASEAN and European countries who have different educational systems originally. The diversity is a challenge to bring the ASEAN education quality to the world level (Sulistyoningrum 2015).

Table 1. Number of Higher Education Institutions (HEIs) in ASEAN

\begin{tabular}{|l|c|c|}
\hline \multicolumn{1}{|c|}{ Country } & $\begin{array}{c}\text { Number of Higher } \\
\text { Education Institutions }\end{array}$ & Year \\
\hline Brunei & 5 & 2016 \\
\hline Cambodia & 211 & 2016 \\
\hline Indonesia & 4.400 & 2016 \\
\hline Lao PDR & 14 & 2015 \\
\hline Malaysia & 111 & 2016 \\
\hline Myanmar & 163 & 2016 \\
\hline Philippines & 2.299 & 2016 \\
\hline Singapore & 11 & 2016 \\
\hline Thailand Total & 155 & 2016 \\
\hline Vietnam & 419 & 2014 \\
\hline \multicolumn{2}{r|}{} \\
\hline
\end{tabular}

Source: SEAMEO-RIHED, 2016 
Based on the table above, there were 7.788 higher education institutions in 2016 in ASEAN which Indonesia has the largest amount reaching 4.400 institutions. Indonesia had more than half higher education institutions of ASEAN's total amount. Then followed by Philippines withx 2.299 institutions. Meanwhile, other ASEAN member countries only had hundreds quantity such as Malaysia (111), Vietnam (419), Thailand (155), Myanmar (163), and Cambodia (211). Hereafter, Lao PDR had 14 higher educational institutions. Singapore as a developed country had 11 higher education institutions, and Brunei Darussalam only had 5 higher education institutions.

This higher education institutions amount can be seen as opportunity yet as the thread at the same time. Why? Because higher education institutions, which in this context can be classified as universities, are the reliable and competent institutions to develop better qualities of human resources. To sums it up, the more universities amounts are, the more potential ASEAN has to produce thousands of qualified human resources. On the other hand, the more of universities amounts are could lead to many threads such as the basic of education system differentiation and education facility quality differentiations. Therefore, integration and harmonization across ASEAN member countries education system become really important. In addition, universities mapping in ASEAN is needed to describe the general profile of ASEAN's higher education institutions.

\subsection{Mapping the Universities' Potentials in ASEAN}

ASEAN has several superior quality universities. Hereby will show the leading universities in ASEAN. The parameters used to measure the competitiveness of universities in ASEAN are based on QS University Ranking and The Webometric Ranking of World Universities. QS University Ranking was published annually by the British Quacquarelli Symods that use nine indicators as follow: 1) academic reputation; 2) employer reputation; 3 ) faculty student; 4) citations per paper; 5) paper per faculty; 6) proportion of international faculty; 7) proportion of international student; 8) proportion of inbound exchange students and 9) proportion of outbound exchange students. By 2018, the rank criteria focus more on the quality of research with the addition of 10) faculty staff with PhD 11) paper per faculty 12) citations per paper.

Universities ranking in ASEAN member countries in 2016 which stated based on QS University Ranking are: 


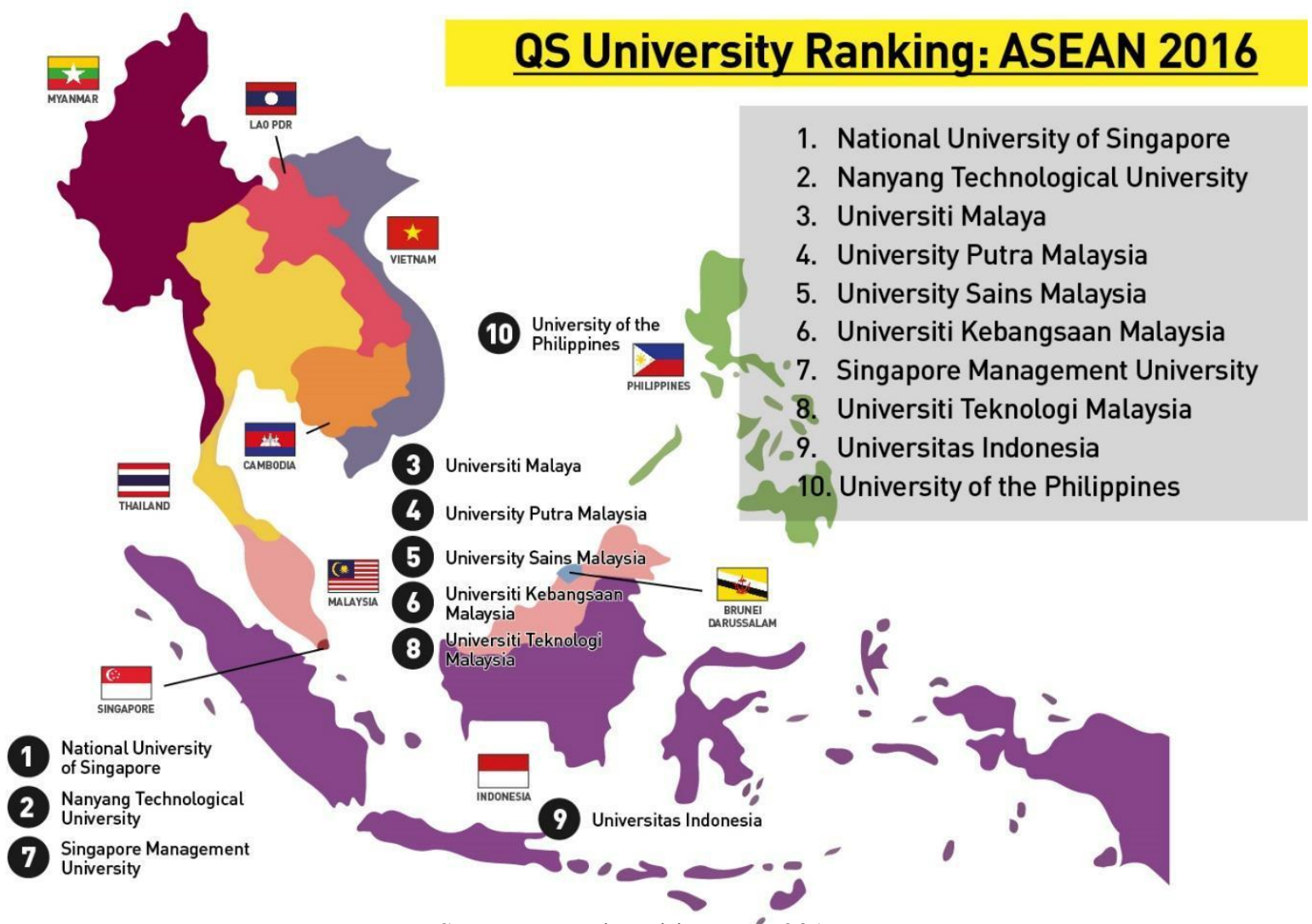

Source: topuniversities.com, 2016

The proportion of university appraisals conducted by QS University Ranking gives a high weight on academic reputation (30\%); faculty: student ratio $(20 \%)$ and citations per paper (15\%) also on Paper per faculty (15\%). This shows that QS University Ranking emphasize on the quality of education, research and publications.

Table 2. QS University Ranking Comparison in 2014 and 2016

\begin{tabular}{|c|c|l|l|c|l|l|}
\hline No & $\begin{array}{c}\text { QS } \\
\text { Ranking } \\
\text { Asia } \\
2014\end{array}$ & University & Country & $\begin{array}{c}\text { QS } \\
\text { Ranking } \\
\text { Asia } \\
2016\end{array}$ & University & Country \\
\hline $\mathbf{1}$ & 1 & $\begin{array}{l}\text { National } \\
\text { University of } \\
\text { Singapore }\end{array}$ & Singapura & 1 & $\begin{array}{l}\text { National } \\
\text { University of } \\
\text { Singapore }\end{array}$ & Singapura \\
\hline $\mathbf{2}$ & 7 & $\begin{array}{l}\text { Nanyang } \\
\text { Technological } \\
\text { University }\end{array}$ & Singapura & 3 & $\begin{array}{l}\text { Nanyang } \\
\text { Technological } \\
\text { University }\end{array}$ & Singapura \\
\hline $\mathbf{3}$ & 32 & Universiti Malaya & Malaysia & 27 & $\begin{array}{l}\text { Universiti } \\
\text { Malaya }\end{array}$ & Malaysia \\
\hline $\mathbf{4}$ & 40 & $\begin{array}{l}\text { Mahidol } \\
\text { University }\end{array}$ & Thailand & 49 & $\begin{array}{l}\text { University } \\
\text { Putra } \\
\text { Malaysia }\end{array}$ & Malaysia \\
\hline
\end{tabular}




\begin{tabular}{|c|c|l|l|c|l|l|}
\hline $\mathbf{5}$ & 48 & $\begin{array}{l}\text { Chulalongkorn } \\
\text { University }\end{array}$ & Thailand & 51 & $\begin{array}{l}\text { University } \\
\text { Sains } \\
\text { Malaysia }\end{array}$ & Malaysia \\
\hline $\mathbf{6}$ & 56 & $\begin{array}{l}\text { Universiti } \\
\text { Kebangsaan } \\
\text { Malaysia }\end{array}$ & Malaysia & 55 & $\begin{array}{l}\text { Universiti } \\
\text { Kebangsaan } \\
\text { Malaysia }\end{array}$ & Malaysia \\
\hline $\mathbf{7}$ & 57 & $\begin{array}{l}\text { Universiti Sains } \\
\text { Malaysia }\end{array}$ & Malaysia & 60 & $\begin{array}{l}\text { Singapore } \\
\text { Management } \\
\text { University }\end{array}$ & Singapura \\
\hline $\mathbf{8}$ & 63 & $\begin{array}{l}\text { University of } \\
\text { Philippines }\end{array}$ & Philippines & 63 & $\begin{array}{l}\text { Universiti } \\
\text { Teknologi } \\
\text { Malaysia }\end{array}$ & Malaysia \\
\hline $\mathbf{9}$ & 66 & $\begin{array}{l}\text { Universiti } \\
\text { Teknologi } \\
\text { Malaysia }\end{array}$ & Malaysia & 67 & $\begin{array}{l}\text { Universitas } \\
\text { Indonesia }\end{array}$ & Indonesia \\
\hline $\mathbf{1 0}$ & 71 & $\begin{array}{l}\text { Universitas } \\
\text { Indonesia }\end{array}$ & Indonesia & 70 & $\begin{array}{l}\text { University of } \\
\text { the } \\
\text { Philippines }\end{array}$ & Philippines \\
\hline
\end{tabular}

Source: QS University Ranking: ASIA in 2014 and 2016

In 2014 and 2016, universities in the top 10 of ASEAN member countries were the universities located in Singapore, Malaysia, Thailand, Philippines and Indonesia. This results also showed that 6 other ASEAN countries namely Brunei Darussalam, Vietnam, Lao PDR, Myanmar and Cambodia need to collaborate on education and research with other ASEAN member countries to improve their education and research quality. We could see that in 2016 there was an improvement of university in Malaysia so that in the same year, there were 5 universities included in the top 10 best universities of ASEAN.

\subsection{The Quality Problem of Education in ASEAN}

Table 3 below shows that there is a gap in high education quality between ASEAN 5 (Singapore, Malaysia, Indonesia, Thailand, also Philippines) and other five ASEAN member countries. This is also supported by the British Council research on International Higher Education (2018) as follows:

Table 3. Overview of the National Policies Framework and countries' scores

\begin{tabular}{|c|c|c|c|c|}
\hline Countries & Overall Score & Openness & $\begin{array}{c}\text { Quality } \\
\text { Assurance } \\
\text { Recognition }\end{array}$ & $\begin{array}{c}\text { Access and } \\
\text { Sustainability }\end{array}$ \\
\hline $\begin{array}{c}\text { Brunei } \\
\text { Darussalam }\end{array}$ & high & high & high & high \\
\hline Cambodia & low & high & high & low \\
\hline Indonesia & high & high & low & very high \\
\hline Lao PDR & low & high & low & low \\
\hline Malaysia & very high & very high & very high & very high \\
\hline Philippines & high & high & high & high \\
\hline Singapore & high & high & high & very high \\
\hline
\end{tabular}




\begin{tabular}{|c|c|c|c|c|}
\hline Thailand & high & very high & high & very high \\
\hline Vietnam & high & high & very high & high \\
\hline Myanmar & low & low & low & low \\
\hline
\end{tabular}

Source: The Shape of Global Higher Education: Understanding the ASEAN Region, Volume 03, British Council, 2018

Note:

- Openness: government-level commitment to internationalisation; environment enabling international mobility of students, researchers, academic programmes and university research

- Quality assurance and recognition: a regulatory environment to facilitate the international mobility of students, education providers and academic programmes

- Access and sustainability: promoting student/academic mobility and international research collaboration; consideration of possible unintended consequences of internationalisation.

Based on data from the British Council's research, we could see that there are significant gaps in openness, quality assurance and recognition, as well as the access and sustainability among the majority of ASEAN member countries compared to Lao PDR, Cambodia, and Myanmar. Besides, there is also a need to improve the research quality in order to build the World University, just as Singapore and Malaysia that succeeded in becoming the part of World University due to its excellent research quality.

One of the effort made to minimize the gap of ASEAN's higher education quality is through ASEAN Connectivity. ASEAN Connectivity is believed to be the mechanism that supports better collaborations in the sustainable infrastructure development, the increased access to knowledge and technology, the enhanced coordination among government agencies in the education sector, as well as in building the harmonization standard and recognition within various education policies in ASEAN.

\section{Literature Review and Framework Idea}

\subsection{Regionalism}

Regionalism is derived from the word "region" which means the region of a particular region. Regionalism is now defined as part of the world, which includes several adjacent states that share common interests. Regionalism is stated to be a continuous cooperation between some countries in the world that cooperate in a single bond (Rahman dan Madiong 2017, 14).

Based on regionalism theory, this research uses sovereignty-centric approaches. Sovereignty is a twofold concept with an external and internal dimension. A state as a 'sovereign' does not recognise an external superior, nor does it accept an internal equal.

Therefore, sovereignty gives state control a legitimate basis. Caporaso $(1996,35)$ said that at the bottom line, sovereignty is a right, a socially recognized capacity to decide matters within a state's jurisdiction (Wunderlich 2007, 16). 


\subsection{Regionalism in Globalisation}

The regionalisation process in the context of global changes can be treated as a phenomenon that happened as a result of creating vast integrated regions which is the only possible response to challenges posted by the increasing polarisation as the result from the globalisation process (Amin 1999). Consequently, regionalisation translates in building various blocks for the purpose of reconstructing the existing global system (Tylec 2017, 29).

Hence, globalism nowadays can also be defined as a global dimension of regionalism, understood as state-led projects aimed to reorganise a given regional space in accordance with specific political and economic goals (Gamble and Payne 2003). Regionalism as a state-led projects can be developed or modified. Consequently, they can constitute a basis for other structures such as globalisation or regionalisation. Regionalisation relates to the process that strengthen integration in specific area, and based on this research topic, it is education.

Relations between regional processes and globalisation can be analysed in their ideological and empirical context. Regionalism refers to identity, ideas, and ideologies relayed to regional projects. In consequence, as a process connected with implementing political projects it should be perceived by globalism. On the other hand, regionalism as an ideology refers to a life style in a geopolitical territory larger than a country, but not in a global sense (Tylec 2017, 30).

The ASEAN cooperation has been developed from time to time, for example is by the enactment of ASEAN Community on December 31, 2015. ASEAN Community is defined as the process to realize the goals of ASEAN and to make ASEAN remains relevant in regional and global dynamics developments. Education plays an important role in the establishment of ASEAN Community. Why? Because through education cooperation among ASEAN member countries could help to improve the quality of human resources also to build a superior competitiveness. Various higher education cooperation in regionalism to globalization concept such as student exchange, faculty, and research staff could help to improve the quality of higher education. Educational cooperation could also be done by conducting various research cooperation programs and the existence of quality assurance standards with regional and global levels. AUN and SHARE programs exist as the proof of regional education implementation in globalization era.

\subsection{Connectivity}

ASEAN as the concept of connectivity for regional development in South-East Asia gain benefits in multiple area for each country members. As stated by Shuib and Lie (2017), this connectivity concept in ASEAN has been formed through historical background. For ASEAN community building, enhancing connectivity is the most important task, with

ASEAN having adopted the ASEAN Leader's Statement on ASEAN Connectivity in 2009 and the Master Plan on ASEAN Connectivity in 2010. The concept of integration is consisted of three pillars:

1. Physical connectivity, which includes transportation, telecommunications and energy networks.

2. Institutional connectivity, which includes trade, investment, liberalization and facilitation of the service sector.

3. People-to-people connectivity, which includes education, tourism and cultural exchange.

This research is based on ASEAN connectivity from higher education sectors. Connectivity plays a role in helping to reduce education gaps among ASEAN member countries. 


\section{Research Method}

As stated, the purpose of this research is to create a better understanding about higher education within ASEAN Connectivity. Connectivity is the success key in building the ASEAN community. Connectivity plays a role in helping to reduce education gaps among ASEAN member countries. Framework of higher education within ASEAN connectivity will strengthen regional cooperation between university institutions and students in ASEAN, also will enhance the internationalization of competitive and high-quality education. This paper is focused on qualitative approach with secondary research. Based on Steward and Kamins (1993), secondary research process has four steps is 1) Identifying the subject domain and where to acquire the information; 2) gathering existing data; 3) Comparing data from different sources; and 4) Analysing the data.

\section{Result and Discussion}

Connectivity is the key to achieve the succeed ASEAN Community. Therefore, the master plan of ASEAN Connectivity 2025 is aimed to improve the life quality of ASEAN residents also provide opportunities and to promote prosperity through economic and social development. In order to achieve that goal, this Master Plan for ASEAN Connectivity (MPAC) 2025 became a guide to be developed for and be focused on three dimensions: $a$ ). Physical Connectivity, that is to improve the infrastructure in order to develop an integrated transportation system and expand the network of information also the communication technology; b). Institutional Connectivity, that aims to realize policies effectively, especially in trading goods and services facilities as well as the investment; c). People-to-People Connectivity, that expand education, innovation and entrepreneurship opportunity moreover to encourage cultural exchanges in developing human resources quality.

ASEAN region is evolving due to the global dynamics. The establishment of ASEAN Connectivity could be one of the real form that ASEAN is following the globalisation to accelerate the competitive, superior, innovative, and dynamic region.

Hereby the proposed framework to minimize the higher education institutions gap towards the better higher education development with regionalized standard. 


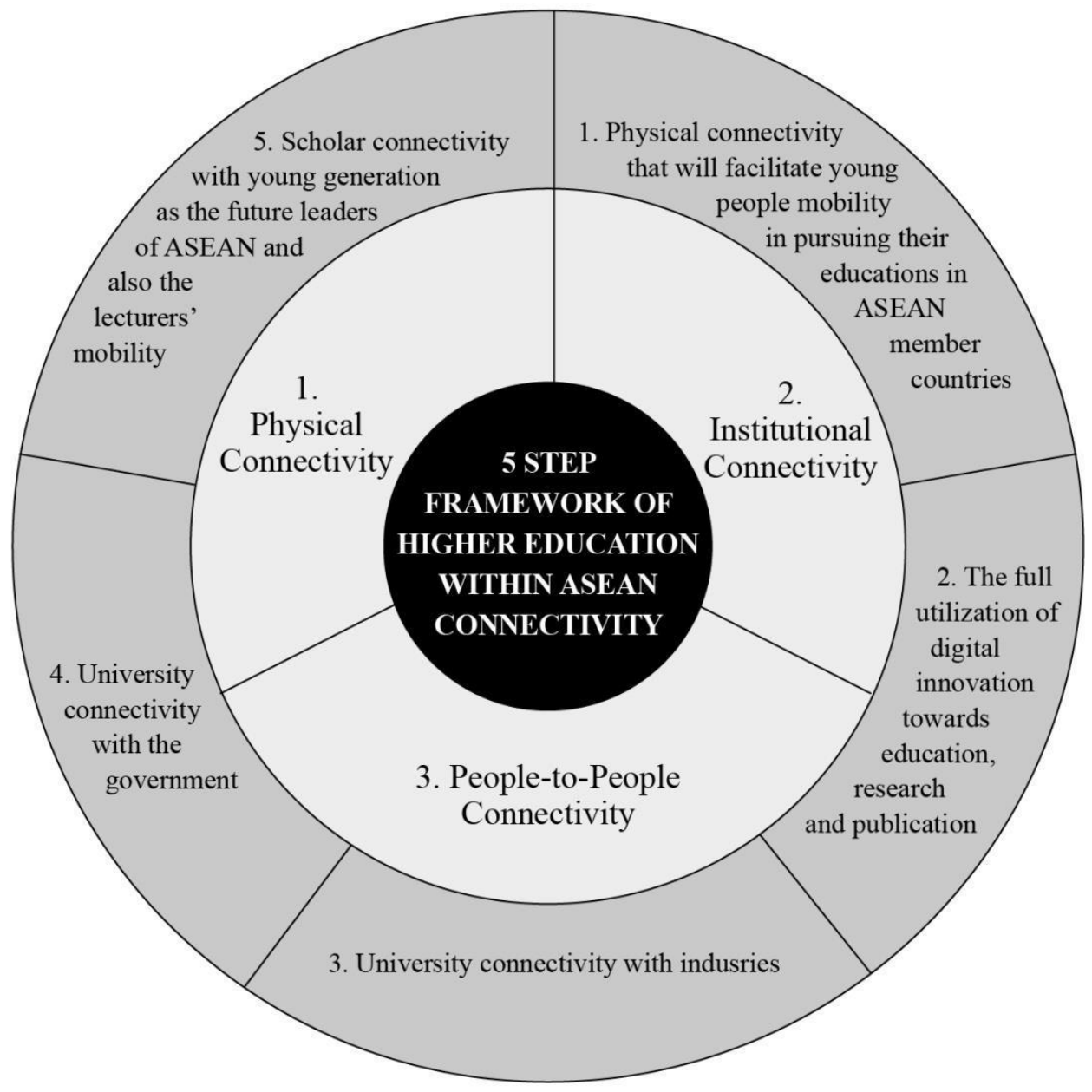

Source: Researcher Data, 2018

Implementation of ASEAN Connectivity to improve the higher education quality and to minimize the gap in ASEAN's higher could be focused on:

First, physical connectivity can be done by building transportation system and highway that will facilitate young people mobility in pursuing their educations in ASEAN member countries. For example, ASEAN Highway Network and the Singapore Kunning Rail Link (SKRL) as the important infrastructure facilities to integrate the bigger, better, and closer ASEAN region in facilitating the regional trade, investment and tourism opportunities, as well as facilitating the lecturers and students in pursuing a better education. In addition, universities as the educational institutions which have important roles in preparing highquality of human resources should improve their facilities and infrastructure in order to support the learning process.

Second, full utilization of digital innovation towards education, research and publication. One implementation forms that the education is well-connected in regional and global scope is through the digital technology. Digital technology innovation could enable the teaching and learning process by online to make everything simpler and give no gap in space and time. Furthermore, the digital tools used by academics and researchers to publish their research results and to access journals will ultimately improve the quality of education. 
Third, one of the ways to improve the high education quality is by producing the graduates with high competencies that match the industrial needs through the lecturing activities. By having competencies that suit the industrial needs, high education graduates are expected to be the answer of industrial needs. Therefore, Universities are expected to encourage the building of connectivity between industries, government and society through institutional connectivity. Universities in ASEAN should always be open to different types of partnerships with any stakeholders. universities connectivity with industries need is expected to focus first on 8 Mutual Recognition Agreement (MRA) that has been agreed by ASEAN, such as MRA on Engineering Services, MRA on Nursing Services, MRA on Architectural Services, MRA on Tourism Professional, MRA on Accountancy Services, MRA on Medical Practitioners, MRA on Dental Practitioners, MRA on Surveying Qualification.

The partnership between universities and industries should also focus on the Priority Integration Sectors as the strategic-valued sectors to advance and be accelerated in the opening of single market with production base. Minister of Economy in ASEAN member countries in Special Informal AEM Meeting, 2003 in Jakarta, have agreed 11 sectors that include in Priority Integration Sectors and 1 other sector that have been agreed in Philippines. These 12 sectors consist of 7 sectors of trade in goods, namely agricultural products, automotive, electronics, fisheries, rubber products, textiles \& clothing, wood products, and logistics; as well as 5 services trade sectors namely air transportation, e-ASEAN, health services, logistics, and tourism.

Fourth, in order to overcome the gap in education policy (especially for the openness, quality assurance and recognition, also the access and sustainability), universities in cooperation with governments will need to revamp the regulations that could prevent the universities' creativity and development. For example, ASEAN Community existence will influence the higher education level in Indonesia. Universities' competition is no longer limited to universities in Indonesia, but already includes universities in the ASEAN region. Moreover, the liberalization in service sector also opens opportunities for foreign universities to enter and be established in the territory of Indonesia. This is legally enforceable in accordance with Article 90 of Law No. 12 of 2012 on Higher Education which states that other universities can conduct Higher Education in the Indonesian territory in cooperation with Indonesia's universities as well as under government permits.

ASEAN member countries have made quality assurance in education as the national agenda. Each university determines the quality of each education criteria, in which some consult with other institutions at the national or international level. At the regional level, the ASEAN University Network initiative in establishing quality standards among AUN members can be served as a benchmark standard for the quality of ASEAN universities.

Fifth, the scholar connectivity with young generation as the future leaders of ASEAN. By 2016, the total population in ASEAN reaches more than 600 million people, and more than half of them are under 30 years old. This high number of young age residents presents opportunities and challenges in the same time. The dominant of productive age will push the economic progress of ASEAN in the future, yet at the same time, the challenge that must be addressed is to build a strong and competitive young generation. This is where the role of universities in ASEAN is really important in providing the access to high-quality education and training to build superior human resources. Universities as educational institutions are also responsible for shaping the direction of regional development, for example by increasing understanding and appreciation of the culture as well as traditions and beliefs that exist in the ASEAN region. Cooperation with ASEAN universities are expected not only to share knowledge, but also to share understanding and uphold cultural values. No need to regard cultures as a barrier. As a multicultural region, cultural approach within ASEAN countries is categorized as a requirement to build a good network among universities in ASEAN. The fact 
that ASEAN is a multicultural region with multiple languages, dialects, religions and ethnicities has made ASEAN become a unique region.

This connectivity in education is supported by ASEAN Partners. For example, SHARE (Support to Higher Education in The ASEAN Region) scholarship from European Union, as an inter-ASEAN scholarship scheme with transfer credit system between universities institutions in ASEAN to provides the greater opportunity for students to experience the friendliness, culture and diversity of ASEAN directly by themselves. Launched in May 2015, SHARE is an EU aid program with 10 million Euros worth that aims to test the existing system and improve it by supporting the student exchanges program as well as credit recognition in ASEAN. Students who are participating in the SHARE program are expected to strengthen the regional cooperation between universities, student institutions in ASEAN, and improve the internationalization in education field.

Until the first quarter of 2017, there were 134 undergraduate students from 29 universities in 8 ASEAN member countries. This was higher compared in 2016 which only 16 students from 8 ASEAN countries (Kompas.com, 2 Feb 2017). This scholarship program involves the participation from 8 ASEAN countries' universities as quoted in http://shareasean.eu as follows:

Table 4. Universities in ASEAN as SHARE Partner

\begin{tabular}{|c|c|}
\hline Country & University \\
\hline Cambodia & $\begin{array}{c}\text { Royal University of Phnom Penh, University of Cambodia, } \\
\text { Phnom Penh International University, National University of } \\
\text { Management Cambodia }\end{array}$ \\
\hline Indonesia & $\begin{array}{c}\text { Universitas Indonesia, Universitas Diponegoro, Bogor } \\
\text { Agricultural University, Bina Nusantara University }\end{array}$ \\
\hline Lao PDR & $\begin{array}{c}\text { National University of Laos, Savannakhet University, } \\
\text { Souphanouvong University, Champasack University }\end{array}$ \\
\hline Malaysia & $\begin{array}{c}\text { Universiti Kebangsaan Malaysia, Taylor's University Malaysia, } \\
\text { Universiti Teknologi Malaysia, Universiti Malaysia Sabah }\end{array}$ \\
\hline Myanmar & $\begin{array}{c}\text { University of Yangon, Mandalay University, Myanmar } \\
\text { Maritime University, Yangon University of Economics }\end{array}$ \\
\hline Philippines & $\begin{array}{c}\text { University of the Philippines, University of Santo Tomas, De } \\
\text { La Salle University, Ateneo de Manila University }\end{array}$ \\
\hline Thailand & $\begin{array}{c}\text { Chulalongkorn University, Payap University, King Mongkuts } \\
\text { University of Technology Thonburi, Thammasat University }\end{array}$ \\
\hline Vietnam & $\begin{array}{c}\text { Viet Nam National University, Hanoi University of Science and } \\
\text { Technology, Ho Chi Minh University of Technology and } \\
\text { Education, Hue University. }\end{array}$ \\
\hline
\end{tabular}

Source: website share-asean.eu, 2017

About lecturer's mobility ${ }_{\text {fh }}$ Ms. Urawadee Sriphiromya from the Royal Thai Embassy in Manila, as the speaker in the $5^{\text {th }}$ discourse of the Ambassadors' Lecture Series hosted by The University of Santo Tomas, delivered a lecture on Learning Mobility in the context of ASEAN Integration. Learning Mobility, or the free exchange of students and researchers/lecturer across countries, is one of the goals of ASEAN 2025: Forging Ahead Together. Furthermore, lecturer mobility is one the indicators for internationalisation and is assessed by international accreditation also ASEAN University Network (AUN). The benefits 
of this lecturer's mobility are to create, develop, and maintain networks and to join academic activities across ASEAN.

\section{Conclusion and Recommendations}

Education field as the cooperation dimension in Socio-Cultural Pillar plays an important role in building the educated, competitive, innovative and qualified resources in ASEAN Community era. ASEAN member countries could have competitiveness in ASIA and global level by having the qualified human resources. The three dimensions of ASEAN Connectivity can be applied through the five steps higher education connectivity implementation of ASEAN. Improvement of facilities and infrastructure in educational institutions will actualize the conducive atmosphere in both teaching and learning process. Infrastructure connectivity will make the mobility of ASEAN's young generations in pursuing the education across ASEAN region become much easier. Institutional connectivity will also produce human resources that are not only knowledgeable but also have compatible skills with industry needs in ASEAN. At the regional level, connectivity through ASEAN University Network will build quality standards among AUN members that can be set as a benchmark standard for the quality of universities in ASEAN.

Furthermore, research that can obtain ASEAN's universities mapping in complete and detail is needed immediately. Universities profile mapping could adopt based on best university performance measurement criteria conducted by ASIA University Ranking where the performance indicators are grouped into five areas: 1). Teaching (the learning environment; 2). Research (volume, income and reputation); 3). Citations (research influence); 4). International outlook (staff, students and research); 5). Industry income (knowledge transfer).

The quality of higher education in ASEAN member countries can be improved by making the university grand designs as the following: (1) Affirmation/Closing the gap, to give affirmation to feeble universities so that the quality would not be far different from the highquality universities; (2) Mission differentiation, universities have various characters that affect the difference in their directions development; (3) World Class University, means that minimum 3 universities from each ASEAN member countries could get in to the 500 best universities from QS World Ranking version (https:/www.topuniversities.com/qs-worlduniversity-rankings), which so far there are only universities from Singapore, Malaysia, and Indonesia in the list; (4) Innovation and commercialization, universities should do innovations in all possible fields; (5) Legal and Regulations, all regulations that are considered could obstruct the universities development should be fixed.

ASEAN higher education institutions mapping will be the basis for various policymaking in overcoming the diversity of education systems also to build excellent resources in the future. 


\section{REFERENCES}

\section{Books}

Rahman, Abd., and Madiong, Baso. 2017. Politik Hukum Pertanahan. Makassar: Celebes Media Perkasa.

Shuib, Munir and Lie, Koo Yew. 2017. The Role of the University with a Focus on University-Community Engagement. Malaysia: Penerbit Universiti Sains Malaysia.

Stewart, David W. and Kamins, Michael A. 1993. Secondary Research: Information Sources and Methods. Newbury Park: Sage Publications.

Tylec, Karolina Klecha. 2017. The Theoretical and Practical Dimension of Regionalism in East Asia. London: Palgrave Macmillan.

Wunderlich, Jens-Uwe. 2007. Regionalism, Globalisation and International Order: Europe and Southeast Asia. England: Ashgate Publishing Limited.

\section{Websites}

AUN-QA. 2017. “ASEAN University Network (AUN): AUN-QA Network... What Have We Done for ASEAN?" Accessed on March 28, 2018.

http://aunqa.org/views/front/pdffilesnews09/SESSION\%206_1\%20\%20AUNQA\%20In ternational\%20Conference_PPT\%20session\%206\%20Dr.\%20Nantana_28_03_2017_Fi nal\%20V2.pdf

British Council. 2018. "The Shape of Global Higher Education: Understanding the ASEAN Region, Volume 03". Accessed on May 22, 2018.

https://www.britishcouncil.org/sites/default/files/h233_the_shape_of_asean_higher_edu cation_report_final_v2_web_1.pdf

Latief. 2017. "134 Mahasiswa Raih Beasiswa Kuliah di Negara ASEAN.” Kompas.com, Februari 2, 2017. https://edukasi.kompas.com/read/2017/02/02/15583441/134.maha siswa.raih.beasiswa.kuliah.di.negara.asean.

Master Plan for ASEAN Connectivity 2025. n.d. ASEAN. Accessed on January 15, 2018. http://asean.org/storage/2016/09/Master-Plan-on-ASEAN-Connectivity-20251.pdf

QS Quacquarelli Symonds Limited. 2016. “QS University Rankings: Asia 2016.” Accessed on February 9, 2018. https://www.topuniversities.com/university-rankings/asianuniversity-rankings/2016

SHARE ASEAN. 2017. "SHARE SCHOLARSHIP." Accessed on January 17, 2018. http://www.share-asean.eu/activities/scholarship/about 
Sulistyoningrum, Yulianisa. 2015. "Peningkatan Kualitas Pendidikan Tingkat ASEAN Masih Banyak Tantangan." Kabar24, August 24, 2015. http://kabar24.bisnis.com/read/201508 24/255/465110/peningkatan-kualitas-pendidikan-tingkat-asean-masih-banyak-tantangan

University of Santo Tomas. 2017. "Learning Mobility in Light of ASEAN Integration Lecture." Accessed on January 17, 2018. http://www.ust.edu.ph/events/learningmobility-in-light-of-asean-integration-lecture/ 